\title{
Synthesis and Bacteriostatic Activities of Bis(thiourea) Derivatives with Variable Chain Length
}

\author{
Ainaa Nadiah Abd Halim and Zainab Ngaini \\ Department of Chemistry, Faculty of Resources Science and Technology, Universiti Malaysia Sarawak, \\ 94300 Kota Samarahan, Sarawak, Malaysia
}

Correspondence should be addressed to Zainab Ngaini; nzainab@unimas.my

Received 1 September 2016; Revised 18 November 2016; Accepted 24 November 2016

Academic Editor: Radhey Srivastava

Copyright ( 2016 A. N. Abd Halim and Z. Ngaini. This is an open access article distributed under the Creative Commons Attribution License, which permits unrestricted use, distribution, and reproduction in any medium, provided the original work is properly cited.

\begin{abstract}
A series of 1,4-bis(decoxyphenyl)carbamothioyl-terephthalamide derivatives was successfully synthesised by reaction of benzene1,4-dicarbonyl isothiocyanate intermediates with long alkyl chain. The alkylation was performed via Williamson etherification of 4 -acetamidophenol with bromoalkanes. The synthesised bis(thiourea) derivatives differed in the chain length, $\mathrm{C}_{n} \mathrm{H}_{2 n+1}$, where $n=10,12$, and 14 . The structures of all compounds were characterised by elemental $\mathrm{CHN}$ analysis, IR, ${ }^{1} \mathrm{H}$, and ${ }^{13} \mathrm{C}$ NMR spectroscopies. Bacteriostatic activities of bis(thiourea derivatives which consisted of two folds of $\mathrm{N}-\mathrm{H}, \mathrm{C}=\mathrm{O}$, and $\mathrm{C}=\mathrm{S}$ and long alkyl chain substituents were carried out against Gram-negative bacteria (Escherichia coli, ATCC 25922) via turbidimetric kinetic method. Bis(thiourea) derivatives with $n=10$ and $n=12$ displayed excellent activity against $E$. coli with MIC of $135 \mu \mathrm{g} / \mathrm{mL}$ and $145 \mu \mathrm{g} / \mathrm{mL}$, respectively, while bis(thiourea) derivatives with $n=14$ acted as cutoff point with no antibacterial properties. Similar trend was observed in binding affinity to the active site of enoyl ACP reductase (FabI), which demonstrated binding free energy of $-5.3 \mathrm{Kcal} / \mathrm{mol}$ and -4.9 and $-4.8 \mathrm{Kcal} / \mathrm{mol}$, respectively.
\end{abstract}

\section{Introduction}

Thiourea which is also known as thiocarbamide is a white crystalline solid compound that consists of sulphur and nitrogen atoms. Thiourea moiety has become intensely synthesised due to its ability to undergo structural modifications [1]. The existing of two units of reactive primary amine groups has made thiourea a suitable precursor for a synthesis of many new compounds [2]. Thiourea derivatives are well known to display a broad spectrum of applications in pharmaceutical industry due to their biological properties such as antiparasitic [3], anticancer [4], antioxidant [5, 6], antibacterial [7$10]$, antifungal [11], and anti-HIV [12,13] properties.

The synthesis and antibacterial studies of monothiourea derivative are progressing at the considerable rate while bis(thiourea) compounds are relatively less reported [14]. The presence of two or more thiourea moieties, for example, bis(thiourea), was envisaged to possess better antibacterial activity [15]. This is due to the ability of $\mathrm{C}=\mathrm{S}$ and $\mathrm{N}-\mathrm{H}$ groups in thiourea moieties which can be easily protonated under acidic condition and reacted with the carboxyl and phosphate groups of the bacterial surface and thus enhanced the activity [16].

Incorporation of alkyl chain as substituents in thiourea derivatives has been reported for significant biological properties $[17,18]$. The presence of long alkyl chains was reported to enhance the biological activity of thiourea derivatives [19]. Alkyl chains have the ability to increase lipophilicity and promote the ability of the compound to disrupt microorganism cell wall [20-22].

In this paper, we report on the synthesis of novel 1,4bis(decoxyphenyl)carbamothioyl-terephthalamide derivatives $(\mathbf{2} \mathbf{a}-\mathbf{c})$ bearing alkyl chain of different length $\left(\mathrm{C}_{10}, \mathrm{C}_{12}\right.$, and $\mathrm{C}_{14}$ ). The compounds were demonstrated for antibacterial activities against Gram-negative bacteria (Escherichia coli, ATCC 25922) where the effects of different length of alkyl chains were evaluated. 


\section{Materials and Methods}

Benzene-1,4-dioylchloride was acquired from Acros Organics. Potassium thiocyanate, 1-bromodecane, 1-bromododecane, and 1-bromotetradecane were purchased from Merck $\mathrm{kGaa}$. The solvents were dried and distilled before being used under nitrogen as follows: acetone was distilled over potassium permanganate and acetonitrile was distilled over calcium hydride. All the reagents were used as received without any further purification.

Physical Measurement. Melting points were determined by using Stuart SMP3 melting point apparatus and uncorrected. The elemental CHNS analysis was provided by Universiti Teknologi MARA (UiTM) using Thermo Scientific ${ }^{\text {TM }}$ FLASH $2000 \mathrm{CHNS} / \mathrm{O}$ Analyzers. Infrared (IR) spectra $\left(\nu / \mathrm{cm}^{-1}\right)$ were recorded as $\mathrm{KBr}$ pellets on Perkin Elmer Thermoscientific Smart Omni Transmission Nicolet IS10 Fourier Transform Infrared Spectrometer (FTIR). ${ }^{1} \mathrm{H}$ NMR and ${ }^{13} \mathrm{C}$ NMR spectra were recorded using JEOL ECA 500 spectrometer at $500 \mathrm{MHz}\left({ }^{1} \mathrm{H}\right)$ and $125 \mathrm{MHz}\left({ }^{13} \mathrm{C}\right)$ with the chemical shifts $\delta$ $(\mathrm{ppm})$ reported relative to $\mathrm{DMSO}-\mathrm{d}_{6}$ as standards.

2.1. Synthesis of Benzenamine Derivatives (1a-1c). A mixture of 4-acetamidophenol, bromoalkane, and $\mathrm{K}_{2} \mathrm{CO}_{3}$ in acetone $(20 \mathrm{~mL})$ was heated at reflux constant stirring for $48 \mathrm{~h}$. The reaction mixture was cooled to room temperature and taken to dryness. The solid was stirred for $1 \mathrm{~h}$ with $50 \mathrm{~mL}$ of $2 \%$ sodium hydroxide and filtered and then heated at reflux for $2 \mathrm{~h}$ in ethanol:concentrated hydrochloric acid $(1: 1)$ ratio $(10 \mathrm{~mL}: 10 \mathrm{~mL})$ and allowed to cool to room temperature. Water $(20 \mathrm{~mL})$ was added to the reaction mixture and the layers were separated. The aqueous layer was extracted with dichloromethane $(20 \mathrm{~mL})$. The organic layer was separated, dried over $\mathrm{MgSO}_{4}$, and filtered and solvent was removed in vacuo to afford intermediate compounds $\mathbf{l a}-\mathbf{1 c}$ with yields as follows.

4-(Decyloxy)benzenamine (1a). 4-(Decyloxy)benzenamine (1a) was obtained from N-(4-(decyloxy)phenyl)acetamide (2.92 g, $10 \mathrm{mmol}) .(2.02 \mathrm{~g}, 81 \%)$ as milky white solid, m.p: 136$137^{\circ} \mathrm{C} v_{\max }\left(\mathrm{KBr} / \mathrm{cm}^{-1}\right) 3467(\mathrm{NH}), 2917(\mathrm{CH}), 1509$ (Ar-C), $1169(\mathrm{C}-\mathrm{N}), 1028(\mathrm{C}-\mathrm{O}) . \delta_{\mathrm{H}}\left(500 \mathrm{MHz}, \mathrm{CDCl}_{3}\right) 0.89(3 \mathrm{H}, \mathrm{t}, 1 \mathrm{x}$ $\left.\mathrm{CH}_{3}\right), 1.27-1.72\left(16 \mathrm{H}, \mathrm{m}, 8 \mathrm{x} \mathrm{CH} \mathrm{CH}_{2}\right), 3.82\left(2 \mathrm{H}, \mathrm{t}, 1 \mathrm{x} \mathrm{CH} \mathrm{CH}_{2}\right), 6.71$ $(2 \mathrm{H}, \mathrm{d}, J=7.65 \mathrm{~Hz}, \mathrm{Ar}-\mathrm{H}), 7.33(2 \mathrm{H}, \mathrm{d}, J=8.6 \mathrm{~Hz}, \mathrm{Ar}-\mathrm{H})$, $10.10(2 \mathrm{H}, \mathrm{s}, 1 \mathrm{x} \mathrm{NH}) . \delta_{\mathrm{C}}\left(125 \mathrm{MHz}, \mathrm{CDCl}_{3}\right) 14.2,22.8,26.1$, $29.3,29.4,29.6,29.7,32.0,68.3,115.4,122.3,124.7,159.2$.

4-(Dodecyloxy)benzenamine (1b). 4-(Dodecyloxy)benzenamine (1b) was obtained from N-(4-(dodecyloxy)phenyl)acetamide (3.20 g, $10 \mathrm{mmol})$. (1.92 g, 69\%) as light brown solid, m.p: $139-140^{\circ} \mathrm{C} v_{\max }\left(\mathrm{KBr} / \mathrm{cm}^{-1}\right) 3467(\mathrm{NH}), 2916(\mathrm{CH}), 1509$ $(\mathrm{Ar}-\mathrm{C}), 1169(\mathrm{C}-\mathrm{N}), 1028(\mathrm{C}-\mathrm{O}) . \delta_{\mathrm{H}}\left(500 \mathrm{MHz}, \mathrm{DMSO}-\mathrm{d}_{6}\right)$ $0.84\left(3 \mathrm{H}, \mathrm{t}, 1 \mathrm{x} \mathrm{CH} \mathrm{CH}_{3}\right), 1.23-1.68\left(20 \mathrm{H}, \mathrm{m}, 10 \mathrm{x} \mathrm{CH} \mathrm{CH}_{2}\right), 3.94(2 \mathrm{H}$, t, $1 \mathrm{x} \mathrm{CH}$ ) $7.00(2 \mathrm{H}, \mathrm{d}, J=8.6 \mathrm{~Hz}, \operatorname{Ar}-\mathrm{H}), 7.31(2 \mathrm{H}, \mathrm{d}, J=$ $8.6 \mathrm{~Hz}, \mathrm{Ar}-\mathrm{H}), 10.29(2 \mathrm{H}, \mathrm{s}, 1 \mathrm{x} \mathrm{NH}) . \delta_{\mathrm{C}}\left(125 \mathrm{MHz}, \mathrm{DMSO}_{-} \mathrm{d}_{6}\right)$ 14.0, 22.1, 25.5, 28.6, 28.7, 28.8, 29.0, 29.1, 31.3, 67.8, 115.3, 123.9, $124.5,158.2$.
4-(Tetradecyloxy)benzenamine (1c). 4-(Tetradecyloxy)benzenamine (1c) was obtained from N-(4-(tetradecyloxy)phenyl) acetamide (3.50 g, $10 \mathrm{mmol})$. (2.80 g, 91\%) as off-white solid, m.p: $142-143^{\circ} \mathrm{C} \nu_{\max }\left(\mathrm{KBr} / \mathrm{cm}^{-1}\right) 3467(\mathrm{NH}), 2915(\mathrm{CH}), 1510$ (Ar-C), $1169(\mathrm{C}-\mathrm{N}), 1039(\mathrm{C}-\mathrm{O}) . \delta_{\mathrm{H}}\left(500 \mathrm{MHz}, \mathrm{DMSO}-\mathrm{d}_{6}\right)$ $0.85(3 \mathrm{H}, \mathrm{t}, 1 \mathrm{x} \mathrm{CH}), 1.23-1.98\left(24 \mathrm{H}, \mathrm{m}, 12 \mathrm{x} \mathrm{CH} \mathrm{CH}_{2}\right), 3.94(2 \mathrm{H}$, $\left.\mathrm{t}, 1 \mathrm{x} \mathrm{CH}_{2}\right), 7.01(2 \mathrm{H}, \mathrm{d}, J=9.55 \mathrm{~Hz}, \operatorname{Ar}-\mathrm{H}), 7.31(2 \mathrm{H}, \mathrm{d}$, $J=8.6 \mathrm{~Hz}, \mathrm{Ar}-\mathrm{H}), 10.25(2 \mathrm{H}, \mathrm{s}, 1 \mathrm{x} \mathrm{NH}) . \delta_{\mathrm{C}}(125 \mathrm{MHz}, \mathrm{DMSO}-$ $\left.\mathrm{d}_{6}\right)$ 14.0, 22.1, 25.5, 28.6, 28.7, 28.8, 29.0, 30.7, 31.3, 67.8, 115.3, $124.1,124.3,158.1$

2.2. Synthesis of 1,4-bis(decoxyphenyl)carbamothioyl-terephthalamide Derivatives $(\mathbf{2 a}-\mathbf{2 c})$. A solution of benzene-1,4dioylchloride in dry acetone $(20 \mathrm{~mL})$ was added into a suspension of potassium thiocyanate in dry acetone $(20 \mathrm{~mL})$. The mixture was stirred at room temperature to form precipitate. The mixture was filtered and the white $\mathrm{KCl}$ was removed. The filtrate was used directly in next step. Triethylamine was added dropwise to benzenamine derivatives (1a-1c) in dry acetone $(20 \mathrm{~mL})$. The mixture was added to the filtrate. The reaction mixture was stirred at room temperature for $4 \mathrm{~h}$ and filtered. The crude solid was recrystallised in DMF : $\mathrm{MeOH}$ $(1: 1)$ mixture. The preparation of $\mathbf{2 a}-\mathbf{2} \mathbf{c}$ with benzenamine derivatives la-1c ( $\mathrm{g}, \mathrm{mmol})$ and yield is shown as follows.

N1,N4-bis[(4-Decoxyphenyl)carbamothioyl]terephthalamide (2a). N1,N4-bis[(4-decoxyphenyl)carbamothioyl]tereph-thalamide (2a) was obtained from 4-(decyloxy)benzenamine la $(0.25 \mathrm{~g}, 1 \mathrm{mmol}) .(0.26 \mathrm{~g}, 69 \%)$ as bright yellow, m.p: 199- $200^{\circ} \mathrm{C}$; (Found: C, 67.46; H, 7.76; N, 7.49; S, 8.52. $\mathrm{C}_{42} \mathrm{H}_{58} \mathrm{~N}_{4} \mathrm{O}_{4} \mathrm{~S}_{2}$, Requires $\left.\mathrm{C}, 67.5 ; \mathrm{H}, 7.8 ; \mathrm{N}, 7.5 ; \mathrm{S}, 8.6 \%\right) ; v_{\max }$ $\left(\mathrm{KBr} / \mathrm{cm}^{-1}\right) 3393(\mathrm{NH}), 2922(\mathrm{CH}), 1668$ (C=O amide), 1531 (Ar-C), $1244(\mathrm{C}=\mathrm{S}), 1144(\mathrm{C}-\mathrm{N}), 1116(\mathrm{C}-\mathrm{O}) . \delta_{\mathrm{H}}(500 \mathrm{MHz}$, $\left.\mathrm{CDCl}_{3}\right) 0.88\left(6 \mathrm{H}, \mathrm{t}, 2 \mathrm{x} \mathrm{CH} \mathrm{CH}_{3}\right), 1.28-1.80\left(32 \mathrm{H}, \mathrm{m}, 16 \mathrm{x} \mathrm{CH} \mathrm{CH}_{2}\right)$, $3.97\left(4 \mathrm{H}, \mathrm{t}, 2 \mathrm{x} \mathrm{CH} \mathrm{CH}_{2}\right), 6.94(4 \mathrm{H}, \mathrm{d}, J=9.15 \mathrm{~Hz}, \mathrm{Ar}-\mathrm{H}), 7.56$ $(4 \mathrm{H}, \mathrm{d}, J=9.2 \mathrm{~Hz}, \mathrm{Ar}-\mathrm{H}), 8.05$ (4H, s, Ar-H), $9.14(2 \mathrm{H}, \mathrm{s}, 2 \mathrm{x}$ $\mathrm{NH}), 12.25(2 \mathrm{H}, \mathrm{s}, 2 \mathrm{x} \mathrm{NH}) . \delta_{\mathrm{C}}\left(125 \mathrm{MHz}, \mathrm{CDCl}_{3}\right) 14.2,22.8$, 26.1, 29.3, 29.4, 29.5, 29.7, 32.0, 68.4, 114.8, 125.9, 128.4, 158.2, $165.5,178.2$.

N1,N4-bis[(4-Dodecoxyphenyl)carbamothioyl]terephthalamide (2b). N1,N4-bis[(4-dodecoxyphenyl)carbamothioyl] terephthalamide (2b) was obtained from 4-(dodecyloxy)benzenamine $\mathbf{1 b}(0.29 \mathrm{~g}, 1 \mathrm{mmol})$. (0.24 g, 60\%) as light yellow solid, m.p: 202-203 ${ }^{\circ} \mathrm{C}$; (Found: C, 68.78; H, 8.28; N, 7.03; S, 8.03. $\mathrm{C}_{46} \mathrm{H}_{66} \mathrm{~N}_{4} \mathrm{O}_{4} \mathrm{~S}_{2}$, Requires C, 68.8; H, 8.3; N, 7.0; S, 8.0\%); $\nu_{\max }$ $\left(\mathrm{KBr} / \mathrm{cm}^{-1}\right) 3397(\mathrm{NH}), 2921(\mathrm{CH}), 1668$ (C=O amide), 1532 (Ar-C), $1245(\mathrm{C}=\mathrm{S}), 1145(\mathrm{C}-\mathrm{N}), 1117(\mathrm{C}-\mathrm{O}) . \delta_{\mathrm{H}}(500 \mathrm{MHz}$, $\left.\mathrm{CDCl}_{3}\right) 0.88\left(6 \mathrm{H}, \mathrm{t}, 2 \mathrm{x} \mathrm{CH} \mathrm{CH}_{3}\right), 1.26-1.81\left(40 \mathrm{H}, \mathrm{m}, 20 \mathrm{x} \mathrm{CH} \mathrm{CH}_{2}\right)$, $3.97\left(4 \mathrm{H}, \mathrm{t}, 2 \mathrm{x} \mathrm{CH} \mathrm{CH}_{2}\right), 6.95(4 \mathrm{H}, \mathrm{d}, J=9.15 \mathrm{~Hz}, \mathrm{Ar}-\mathrm{H}), 7.56$ $(4 \mathrm{H}, \mathrm{d}, J=9.15 \mathrm{~Hz}, \mathrm{Ar}-\mathrm{H}), 8.06(4 \mathrm{H}, \mathrm{s}, \mathrm{Ar}-\mathrm{H}), 9.10(2 \mathrm{H}, \mathrm{s}, 2 \mathrm{x}$ $\mathrm{NH}), 12.24(2 \mathrm{H}, \mathrm{s}, 2 \mathrm{x} \mathrm{NH}) . \delta_{\mathrm{C}}\left(125 \mathrm{MHz}, \mathrm{CDCl}_{3}\right) 13.1,21.5$, 24.9, 28.1, 28.2, 28.4, 28.5, 30.8, 67.1, 113.4, 125.0, 127.7, 129.6, $135.1,156.6,166.5,178.3$.

N1,N4-bis[(4-Tetradecoxyphenyl)carbamothioyl]terephthalamide (2c). N1,N4-bis[(4-tetradecoxyphenyl)carbamothioyl]terephthalamide (2c) was obtained from 4-(tetradecyloxy)benzenamine 1c $(0.31 \mathrm{~g}, 1 \mathrm{mmol}) .(0.20 \mathrm{~g}, 46 \%)$ as yellow 
<smiles>CC(=O)Nc1ccc(O)cc1</smiles>

$\mathbf{R}, \mathbf{2 a}=\mathrm{C}_{10} \mathrm{H}_{21}$ $\mathbf{2 b}=\mathrm{C}_{12} \mathrm{H}_{25}$ $2 \mathbf{c}=\mathrm{C}_{14} \mathrm{H}_{29}$ (i) $\mathrm{R}-\mathrm{Br}, \mathrm{K}_{2} \mathrm{CO}_{3}$, acetone,

$$
2 \% \mathrm{NaOH}
$$

(ii) $\mathrm{CH}_{3} \mathrm{CH}_{2} \mathrm{OH}$, Conc. $\mathrm{HCl}$<smiles>[R]Oc1ccc(N)cc1</smiles><smiles>[13CH3]</smiles><smiles>O=C(Cl)c1ccc(C(=O)Cl)cc1</smiles>

1a-c<smiles>[R]Oc1ccc(NC(=S)NC(=O)c2ccc(C(=O)NC(=S)Nc3ccc(O[R2])cc3)cc2)cc1</smiles>

$2 a-c$

Scheme 1: Synthesis of bis(thiourea) derivatives.

solid, m.p: $208-210^{\circ} \mathrm{C}$; (Found: C, 69.98; H, 8.72; N, 7.36; $\mathrm{S}, 7.49 . \mathrm{C}_{50} \mathrm{H}_{74} \mathrm{~N}_{4} \mathrm{O}_{4} \mathrm{~S}_{2}$, Requires $\mathrm{C}$, 69.9; H, 8.7; N, 7.4; S, $7.5 \%) ; v_{\max }\left(\mathrm{KBr} / \mathrm{cm}^{-1}\right) 3397(\mathrm{NH}), 2918(\mathrm{CH}), 1669(\mathrm{C}=\mathrm{O}$ Amide), 1531 (Ar-C), 1244 (C=S), 1148 (C-N), 1117 (C-O). $\delta_{\mathrm{H}}\left(500 \mathrm{MHz}, \mathrm{CDCl}_{3}\right) 0.88\left(6 \mathrm{H}, \mathrm{t}, 2 \mathrm{x} \mathrm{CH}_{3}\right), 1.26-1.80(48 \mathrm{H}$, $\left.\mathrm{m}, 24 \mathrm{x} \mathrm{CH}_{2}\right), 3.98\left(4 \mathrm{H}, \mathrm{t}, 2 \mathrm{x} \mathrm{CH} \mathrm{CH}_{2}\right), 6.95(4 \mathrm{H}, \mathrm{d}, J=8.6 \mathrm{~Hz}$, Ar-H), $7.56(4 \mathrm{H}, \mathrm{d}, J=8.6 \mathrm{~Hz}, \mathrm{Ar}-\mathrm{H}), 8.06(4 \mathrm{H}, \mathrm{s}, \mathrm{Ar}-\mathrm{H})$, $9.05(2 \mathrm{H}, \mathrm{s}, 2 \mathrm{x} \mathrm{NH}), 12.23(2 \mathrm{H}, \mathrm{s}, 2 \mathrm{x} \mathrm{NH}) . \delta_{\mathrm{C}}(125 \mathrm{MHz}$, $\left.\mathrm{CDCl}_{3}\right)$ 14.2, 22.8, 26.1, 29.3, 29.5, 29.7, 29.8, 32.0, 68.3, 114.8, $125.9,128.4,130.1,136.2,158.2,165.6,178.0$.

2.3. Antibacterial Screening. The synthesised bis(thiourea) compounds $\mathbf{2 a - 2} \mathbf{c}$ were screened for the antibacterial activities against Gram-negative bacteria E. coli and employing turbidimetric kinetic method. The bacteria were cultured on Luria-Bertani (LB) agar for $24 \mathrm{~h}$ at $37^{\circ} \mathrm{C}$. The inoculums were prepared by allowing bacteria to grow on media containing nutrient broth at $37^{\circ} \mathrm{C}$ with permanent stirring at $250 \mathrm{rpm}$ for $18 \mathrm{~h}$. The inoculums $(0.2 \mathrm{~mL})$ were inoculated with $10 \mathrm{~mL}$ of culture medium (with increasing concentration of the compounds dissolved in propanol). The mixture was shaken at $180 \mathrm{rpm}$ at $37^{\circ} \mathrm{C}$. Inoculums with propanol were used as a control. Aliquots of each replicates were taken at every $1 \mathrm{~h}$ interval for $6 \mathrm{~h}$. The transmittances $(T)$ were recorded using a UV-Visible spectrophotometer (Optima SP-300). The antibacterial activities were determined by plotting a graph of $\ln N t$ versus time. The $\ln N t$ is defined as transmittance value, which represents the number colony forming units (CFU) $\mathrm{mL}^{-1}$ for bacteria versus time following expressions: E. coli $\ln N t=27.1-8.56 T$ [23].

2.4. Molecular Docking. The docking studies on $2 \mathbf{a}-2 \mathbf{c}$ were carried out using AutoDock Vina 1.1.2 program [24]. The polar hydrogens of the compounds and protein were added with AutoDock Tools 1.5.6 [25] prior to docking with AutoDock Vina program. The cubic grid box of $60 \AA$ size $(x, y$, and $z$ ) with a spacing of $0.375 \AA$ were centred on the active site of the protein. The X-ray crystal structure of the enzyme enoyl ACP reductase (FabI) of E. coli (PDB entry: 1C14) was retrieved from Protein Data Bank (http://www.rcsb.org/pdb/ home/home.do) [26].

\section{Results and Discussion}

3.1. Chemistry. The synthesis of bis(thiourea) $\mathbf{2 a}-\mathbf{2 c}$ involved multiple steps reactions. The reaction involved alkylation of 4-acetamidophenol with a series of bromoalkanes $\left(\mathrm{C}_{10}, \mathrm{C}_{12}\right.$, and $\mathrm{C}_{14}$ ) in the presence of $\mathrm{K}_{2} \mathrm{CO}_{3}$ followed by hydrolysis to form benzenamine derivatives (intermediate) 1a-1c. The reaction of intermediate $\mathbf{1 a - 1 c}$ prior to deprotonation by TEA for $3 \mathrm{~h}$ at room temperature gave bis(thiourea) $2 \mathrm{a}-\mathbf{2 c}$ with moderate yields of $46-69 \%$. The synthesis route of $2 a-2 c$ is illustrated in Scheme 1.

The IR spectra showed the successful formation of $\mathbf{2 a - 2 c}$ with the presence of frequencies at $3397-3393 \mathrm{~cm}^{-1}$ attributed to $v_{\mathrm{NH}}$ band. The absorption attributed to aliphatic carbon chain was observed at $2922-2918 \mathrm{~cm}^{-1}$, while strong absorption band at $1669-1668 \mathrm{~cm}^{-1}$ corresponded to $v_{\mathrm{C}=\mathrm{O}}$ amide. The aromatic ring was represented by the absorption bands at $1532-1531 \mathrm{~cm}^{-1}$. The $v_{\mathrm{C}=\mathrm{S}}$ absorption bands were observed at $1245-1244 \mathrm{~cm}^{-1}$ which confirmed the formation of thiourea in the compounds [27]. The $v_{\mathrm{C}-\mathrm{N}}$ absorption band was observed at $1148-1144 \mathrm{~cm}^{-1}$ [28].

Further confirmation of the formation of $\mathbf{2 a - 2 c}$ was supported by ${ }^{1} \mathrm{H}$ and ${ }^{13} \mathrm{C}$ NMR spectroscopies. The two singlets attributed to $\mathrm{CSNH}$ and $\mathrm{CONH}$ peak were observed at $12.25-12.23 \mathrm{ppm}$ and $9.14-9.05 \mathrm{ppm}$, respectively, which indicated the formation of thiourea [7]. The peak of CSNH 
$2 \mathrm{a}$

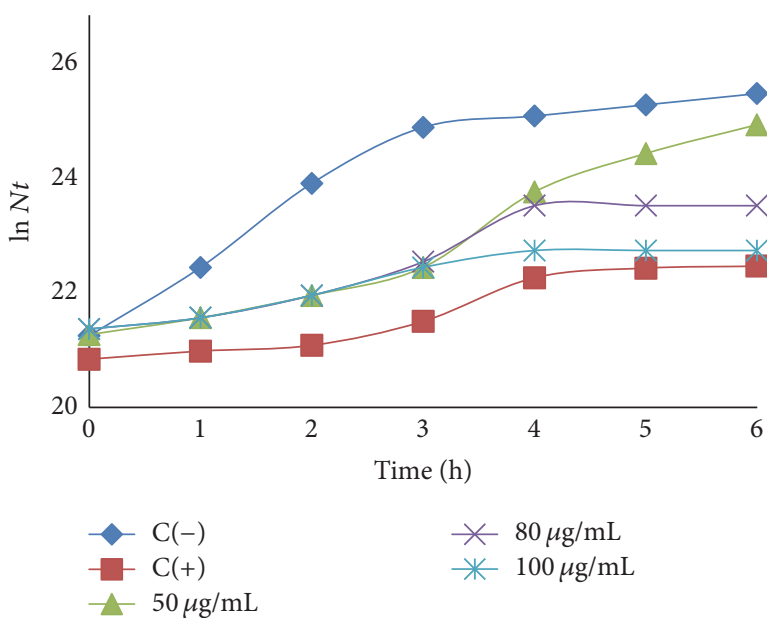

(a)
$2 b$

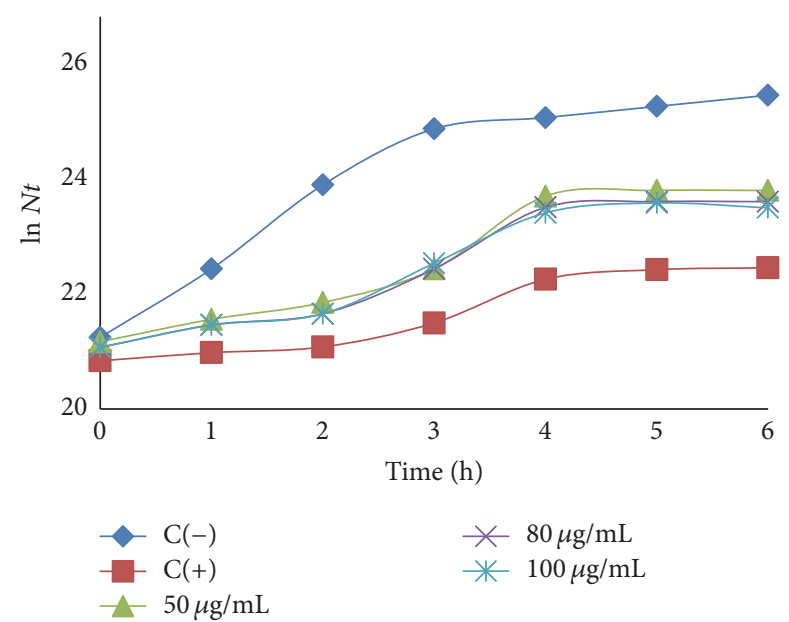

(b)

$2 \mathrm{c}$

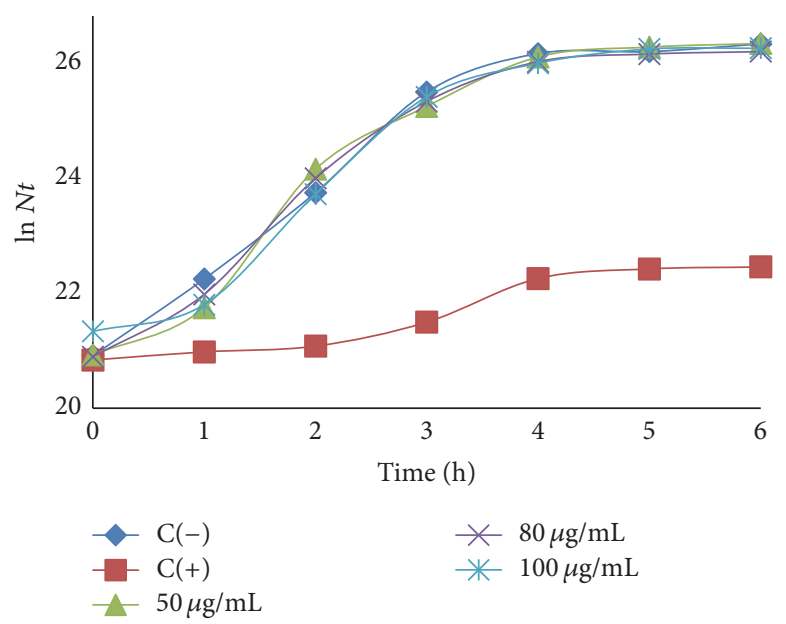

(c)

FIGURE 1: Growth of E. coli in media containing compounds: (a) 2a, (b) 2b, and (c) 2c.

was at higher chemical shift due to deshielding effect [18]. Multiple peaks observed at 8.06-6.94 ppm were assigned to aromatic protons. The resonance as triplet at $3.97 \mathrm{ppm}$ was attributed to $-\mathrm{OCH}_{2}$ while alkyl chain $\left(-\mathrm{CH}_{2}\right)$ was represented by the peaks at $0.88-1.81 \mathrm{ppm}$.

The resonance of ${ }^{13} \mathrm{C}$ NMR at 178.3-178.2 ppm and 166.4$165.5 \mathrm{ppm}$ was attributed to $\mathrm{C}=\mathrm{S}$ and $\mathrm{C}=\mathrm{O}$, respectively. The multiple resonances observed at $158.2-113.4 \mathrm{ppm}$ were assigned to aromatic carbons in the compound. The $-\mathrm{OCH}_{2}$ was observed at 68.4-67.1 ppm while $-\mathrm{CH}_{2}$ was observed as multiple resonances due to the number of carbon chains at 32.0-13.1 ppm. The $-\mathrm{OCH}_{2}$ peak appeared at higher frequency compared to alkyl $-\mathrm{CH}_{2}$ resonance due to downfield effect as it has been attached to higher electronegative atom (oxygen) [29].

3.2. Antibacterial Activity and Docking. The synthesised bis(thiourea) derivatives $\mathbf{2 a}-\mathbf{2} \mathbf{c}$ were screened for antibacterial activities using turbidimetric kinetic method. Compounds 2a-2c were examined at the concentration of $50 \mu \mathrm{g} / \mathrm{mL}$, $80 \mu \mathrm{g} / \mathrm{mL}$, and $100 \mu \mathrm{g} / \mathrm{mL}$ against Gram-negative bacteria $E$. coli ATCC 25922. The result for an antibacterial assay for each compound is shown in Figure 1. The results were represented by graphs of $\ln N t$ versus time $(t)$ where $\ln N t$, defined as transmittance value, corresponded to the number of colony forming units $(\mathrm{CFU}) \mathrm{mL}^{-1}$ for $E$. coli versus time following expression $\ln N t=27.1-8.56 T$ [23]. Compounds $\mathbf{2 a}$ and $\mathbf{2 b}$ showed excellent inhibition against $E$. coli compared to $2 \mathbf{c}$.

The minimum inhibitory concentration (MIC) was also performed by extrapolating the concentration at the zero growth rate of E. coli $(\mu=0)$ [30]. MIC is the lowest concentration of the antimicrobial agent that inhibits the development of visible growth after overnight incubation and use to confirm the resistance of microorganisms to the antibacterial agent [31]. Propanol was used as negative control and 


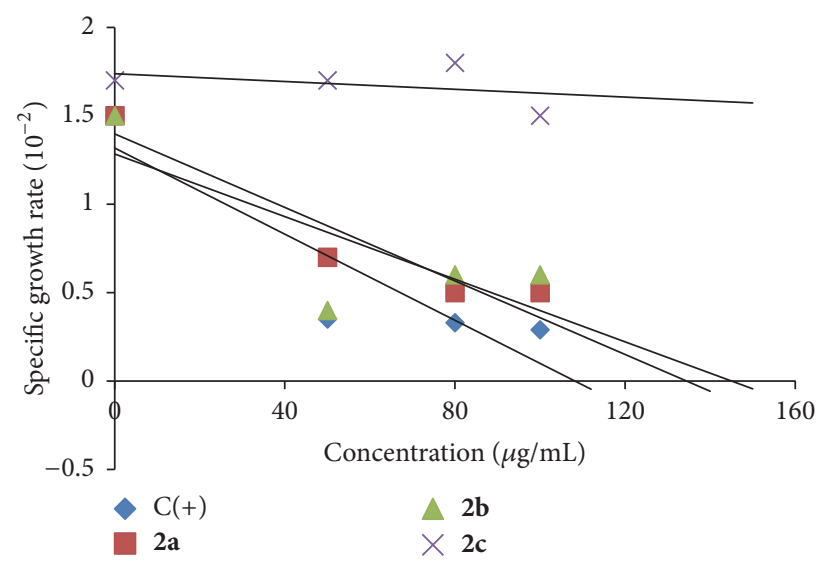

Figure 2: Minimum inhibitory concentration of 2a-2c against E. coli.

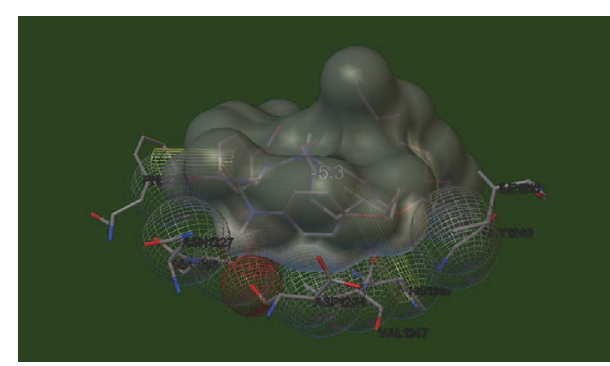

(a)

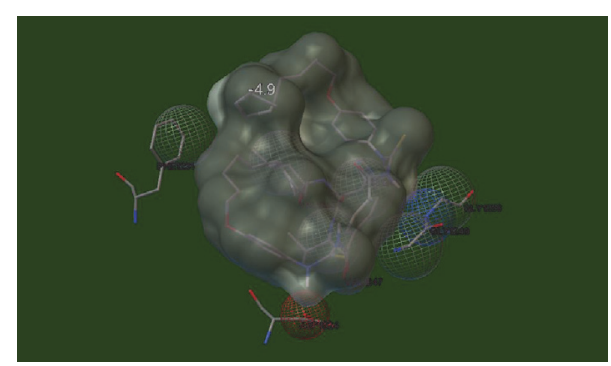

(b)

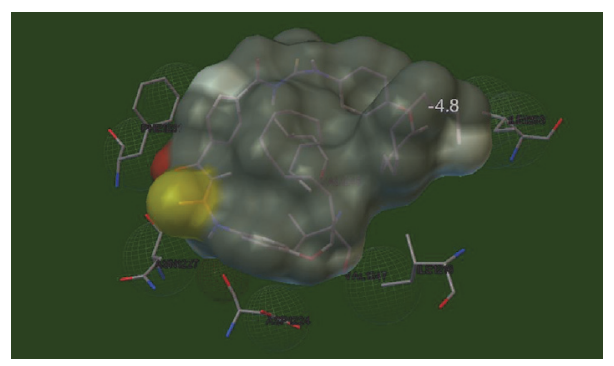

(c)

FIgURE 3: The molecular binding of (a) 2a, (b) 2b, and (c) 2c with enzyme enoyl ACP reductase (FabI) of E. coli.

ampicillin as positive control. The MIC of $\mathbf{2 a - 2} \mathbf{c}$ is shown in Figure 2.

The MIC data obtained showed that both $\mathbf{2 a}$ and $\mathbf{2} \mathbf{b}$ exhibited excellent antibacterial activities with MIC values of $135 \mu \mathrm{g} / \mathrm{mL}$ and $145 \mu \mathrm{g} / \mathrm{mL}$, respectively. The MIC value of ampicillin was observed at $108 \mu \mathrm{g} / \mathrm{mL}$. The MIC values less than $200 \mu \mathrm{g} / \mathrm{mL}$ can be suggested for pharmacological purposes [32]. It was believed that the antibacterial activities of $\mathbf{2} \mathbf{a}$ and $\mathbf{2} \mathbf{b}$ were due to the lipophilic character of the long alkyl chain which has the ability to disrupt microorganism cell wall $[20,21]$.

However, the antibacterial activities of the compounds decreased as the alkyl chains increased. Compound $2 \mathrm{c}$ with $\mathrm{C}_{14}$ alkyl chains, for instance, showed the MIC values of $>200 \mu \mathrm{g} / \mathrm{mL}$. This phenomenon was due to the cutoff effect where the compound demonstrated a parabolic effect as the alkyl chain lengths increased from 14 to 16 [20]. In comparison to $\mathbf{2} \mathbf{a}$ and $\mathbf{2} \mathbf{b}, \mathbf{2} \mathbf{c}$ which has the longest carbon chain could have imitated the molecule in the lipid bilayer of organism and afforded less disruption in the bacteria membrane [33].

For the further understanding of the interactions between Gram-negative bacteria E. coli and bis(thiourea) derivatives $\mathbf{2 a - 2} \mathbf{c}$ as potential antibacterial agents, $\mathbf{2 a - 2} \mathbf{c}$ were interacted via docking to the active site of the enzyme enoyl ACP reductase (FabI) of E. coli (PDB entry: 1C14) using AutoDock Vina 1.1.2 program [24-26]. The binding interaction for $\mathbf{2 a - 2 c}$ is shown in Figure 3.

The binding affinity of $\mathbf{2} \mathbf{a}-\mathbf{2} \mathbf{c}$ was evaluated based on binding free energies $\left(\Delta G_{b}, \mathrm{Kcal} / \mathrm{mol}\right)$ [34]. Based on the binding model depicted in Figure 3, 2a possessed the highest binding affinity with a binding free energy of $-5.3 \mathrm{Kcal} / \mathrm{mol}$ followed by $\mathbf{2 b}$ and $2 \mathrm{c}$ with -4.9 and $-4.8 \mathrm{Kcal} / \mathrm{mol}$, respectively. Compound $\mathbf{2} \mathbf{a}$ is strongly bound to enzyme enoyl ACP 
reductase (FabI) of $E$. coli through $\pi-\pi$ bond interactions (yellow colour cylindrical wireframe) with hydrophobic pockets of Phe 1231 and His 1246. The hydrophobic interaction between phenyl rings has increased the lipophilicity of the compound [32]. Other basic residues such as Asn 1227, Ser 1228, Asp 1224, Val 1247, Gly 1249, and Ile 1216 (Figure 3) were observed in close proximity to compound $\mathbf{2 a}$, which suggested that a strong electrostatic interaction was also involved in the binding process [35]. On the other hand, the increase of carbon chain in $\mathbf{2 b}$ and $\mathbf{2 c}$ was accountable for lesser binding affinity [36].

\section{Conclusions}

Novels bis(thiourea) derivatives $\mathbf{2 a - 2} \mathbf{c}$ were successfully synthesised and evaluated for antibacterial activities against $E$. coli. The MIC data obtained showed that $\mathbf{2} \mathbf{a}$ and $\mathbf{2 b}$ with $n=10$ and $n=12$ exhibited excellent antibacterial activities with MIC values of $135 \mu \mathrm{g} / \mathrm{mL}$ and $145 \mu \mathrm{g} / \mathrm{mL}$, respectively. The increase of carbon chain has decreased the antibacterial activities. Further studies on the correlation of the molecular structure and binding affinity via molecular docking interaction study revealed the binding interaction of $\mathbf{2 a - 2 c}$ with enzyme enoyl ACP reductase (FabI) of E. coli, in a similar trend to that of the biological activities. Based on the molecular docking and antibacterial assay study, it can be suggested that $\mathbf{2 a}$ is a potential antibacterial agent for pharmaceutical applications.

\section{Competing Interests}

The authors declare that there is no conflict of interests regarding the publication of this paper.

\section{Acknowledgments}

The authors would like to acknowledge Universiti Malaysia Sarawak and Ministry of Education for research funds F07(DPP42)/1262/2015(17) and FRGS/E14099/F07/69/1298/ 2015(15).

\section{References}

[1] M. Ili, M. Bucos, F. Dumitracu, and V. Cîrcu, "Mesomorphic behaviour of N-benzoyl-N/-aryl thioureas liquid crystalline compounds," Journal of Molecular Structure, vol. 987, no. 1-3, pp. 1-6, 2011.

[2] S. Murru, C. B. Singh, V. Kavala, and B. K. Patel, "A convenient one-pot synthesis of thiazol-2-imines: application in the construction of pifithrin analogues," Tetrahedron, vol. 64, no. 8, pp. 1931-1942, 2008.

[3] J. Müller, C. Limban, B. Stadelmann et al., "Thioureides of 2(phenoxymethyl) benzoic acid 4-R substituted: a novel class of anti-parasitic compounds," Parasitology International, vol. 58, no. 2, pp. 128-135, 2009.

[4] J. C. Shing, J. W. Choi, R. Chapman et al., "A novel synthetic 1,3phenyl bis-thiourea compound targets microtubule polymerization to cause cancer cell death," Cancer Biology \& Therapy, vol. 15, no. 7, pp. 895-905, 2014.
[5] C. Saturnino, M. D’Auria, N. Paesano et al., "Antioxidant activity of thioureidic derivatives I," Il Farmaco, vol. 58, no. 9, pp. 823828, 2003.

[6] P. Venkatesh and S. N. Pandeya, "Synthesis and anti-oxidant activity of some $\mathrm{N}$-(anilinocarbonothioyl) benzamide and heterocyclic based thiourea derivatives," International Journal of ChemTech Research, vol. 1, no. 3, pp. 733-741, 2009.

[7] P. B. Kaswala, K. H. Chikhalia, N. K. Shah, D. P. Patel, D. H. Patel, and G. V. Mudaliar, "Design, synthesis and antimicrobial evaluation of s-triazinyl urea and thiourea derivatives," Arkivoc, vol. 2009, no. 11, pp. 326-335, 2009.

[8] Z. Ngaini, M. A. Mohd Arif, H. Hussain, E. S. Mei, D. Tang, and D. H. A. Kamaluddin, "Synthesis and antibacterial activity of acetoxybenzoyl thioureas with aryl and amino acid side Chains," Phosphorus, Sulfur and Silicon and the Related Elements, vol. 187, no. 1, pp. 1-7, 2012.

[9] W. S. H. Wan Zullkiplee, A. N. Abd Halim, Z. Ngaini, M. A. Mohd Ariff, and H. Hussain, "Bis-Thiourea bearing aryl and amino acids side chains and their antibacterial activities," Phosphorus, Sulfur and Silicon and the Related Elements, vol. 189, no. 6, pp. 832-838, 2014.

[10] N. I. M. Halim, K. Kassim, A. H. Fadzil, and B. M. Yamin, "Synthesis, characterisation and antibacterial studies of $\mathrm{Cu}$ (II) complexes thiourea," Malaysian Journal of Analytical Sciences, vol. 16, no. 1, pp. 56-61, 2012.

[11] J. Wu, Q. Shi, Z. Chen, M. He, L. Jin, and D. Hu, "Synthesis and bioactivity of pyrazole acyl thiourea derivatives," Molecules, vol. 17, no. 5, pp. 5139-5150, 2012.

[12] F. M. Uckun, C. Mao, S. Pendergrass et al., "N-[2-(4-methylphenyl)ethyl]-N'-[2-(5-bromopyridyl)]-thiourea as a potent inhibitor of NNRTI-resistant and multidrug-resistant human immunodeficiency virus type 1," Antiviral Chemistry and Chemotherapy, vol. 11, no. 2, pp. 135-140, 2000.

[13] I. Küçükgüzel, E. Tatar, Ş. G. Küçükgüzel, S. Rollas, and E. De Clercq, "Synthesis of some novel thiourea derivatives obtained from 5-[(4-aminophenoxy)methyl]-4-alkyl/aryl-2,4-dihydro$3 \mathrm{H}-1,2,4$-triazole-3-thiones and evaluation as antiviral/antiHIV and anti-tuberculosis agents," European Journal of Medicinal Chemistry, vol. 43, no. 2, pp. 381-392, 2008.

[14] N. I. M. Halim, K. Kassim, A. H. Fadzil, and B. M. Yamin, "Synthesis, characterization and antibacterial studies of benzoylthiourea derivatives," IPCBEE, vol. 14, pp. 55-59, 2011.

[15] M. O. Uwaisulqarni and M. B. Yamin, "Synthesis and structural study of bis-thiourea moieties with aromatic linkers," in Proceedings of the 11th International Annual Symposium on Sustainability Science and Management, Universiti Malaysia Terengganu, 2012.

[16] Z. Zhong, R. Xing, S. Liu, L. Wang, S. Cai, and P. Li, "Synthesis of acyl thiourea derivatives of chitosan and their antimicrobial activities in vitro," Carbohydrate Research, vol. 343, no. 3, pp. 566-570, 2008.

[17] M. Huang, Y. Sun, W. Yang et al., "[583] ACH-806: a potent inhibitor of HCV replication with a novel mechanism of action," Journal of Hepatology, vol. 46, p. S221, 2007.

[18] S. Saeed, N. Rashid, P. G. Jones, M. Ali, and R. Hussain, "Synthesis, characterization and biological evaluation of some thiourea derivatives bearing benzothiazole moiety as potential antimicrobial and anticancer agents," European Journal of Medicinal Chemistry, vol. 45, no. 4, pp. 1323-1331, 2010.

[19] N. S. Reddy, A. S. Rao, M. A. Chari, V. R. Kumar, V. Jyothy, and V. Himabindu, "Synthesis and antibacterial activity of sulfonamide 
derivatives at C-8 alkyl chain of anacardic acid mixture isolated from a natural product cashew nut shell liquid (CNSL)," Journal of Chemical Sciences, vol. 124, no. 3, pp. 723-730, 2012.

[20] C. R. Birnie, D. Malamud, and R. L. Schnaare, "Antimicrobial evaluation of $\mathrm{N}$-alkyl betaines and $\mathrm{N}$-alkyl-N, N-dimethylamine oxides with variations in chain length," Antimicrobial Agents and Chemotherapy, vol. 44, no. 9, pp. 2514-2517, 2000.

[21] K. D. Park, Y. S. Park, S. J. Cho et al., "Antimicrobial activity of 3O-Acyl-(-)-epicatechin and 3-O-Acyl-(+)-catechin derivatives," Planta Medica, vol. 70, no. 3, pp. 272-276, 2004.

[22] Z. Ngaini, S. M. Haris Fadzillah, and H. Hussain, "Synthesis and antimicrobial studies of hydroxylated chalcone derivatives with variable chain length," Natural Product Research, vol. 26, no. 10, pp. 892-902, 2012.

[23] N. B. Pappano, O. N. P. Centorbi De, and F. H. Ferretti, "Determination of the responsible molecular zone for the chalcones bacteriostatic activity," Revista de Microbiologia, vol. 25, no. 3, pp. 168-174, 1994.

[24] O. Trott and A. J. Olson, "Software news and update AutoDock Vina: improving the speed and accuracy of docking with a new scoring function, efficient optimization, and multithreading," Journal of Computational Chemistry, vol. 31, no. 2, pp. 455-461, 2010.

[25] G. M. Morris, H. Ruth, W. Lindstrom et al., "AutoDock4 and AutoDockTools4: automated docking with selective receptor flexibility," Journal of Computational Chemistry, vol. 30, no. 16, pp. 2785-2791, 2009.

[26] S. George, M. B. Ramzeena, S. V. Ram, S. K. Selvaraj, S. Rajan, and T. K. Ravi, "Design, docking, synthesis and anti E. coli screening of novel thiadiazolo thiourea derivatives as possible inhibitors of enoyl ACP reductase (FabI) enzyme," Bangladesh Journal of Pharmacology, vol. 9, no. 1, pp. 49-53, 2014.

[27] A. Saeed, N. Abbas, Z. Ashraf, and M. Bolte, "Synthesis, characterization and antibacterial activity of new 1, 2-and 1, 4-bis (N'-substituted thioureido) benzene derivatives," South African Journal of Chemistry, vol. 66, pp. 273-278, 2013.

[28] A. Saeed, H. Rafique, A. Hameed, and S. Rasheed, "Synthesis and antibacterial activity of some new 1-aroyl-3-(substituted2-benzothiazolyl)thioureas," Pharmaceutical Chemistry Journal, vol. 42, article 191, 2008.

[29] M. K. Rauf, Imtiaz-ud-Din, A. Badshah et al., "Synthesis, structural characterization and in vitro cytotoxicity and anti-bacterial activity of some copper (I) complexes with N, N/-disubstituted thioureas," Journal of Inorganic Biochemistry, vol. 103, no. 8, pp. 1135-1144, 2009.

[30] M. De Los Angeles Alvarez, V. E. P. Zarelli, N. B. Pappano, and N. B. Debattista, "Bacteriostatic action of synthetic polyhydroxylated chalcones against Escherichia coli," Biocell, vol. 28, no. 1, pp. 31-34, 2004.

[31] D. Greenwood, R. Slack, and J. Peutherer, "Medical microbiology," in A Guide to Microbial Infections: Pathogenesis, Immunity, Laboratory Diagnosis and Control, ELST Publishers, Edinburgh, UK, 15th edition, 1997.

[32] H. Arslan, N. Duran, G. Borekci, C. K. Ozer, and C. Akbay, "Antimicrobial activity of some thiourea derivatives and their nickel and copper complexes," Molecules, vol. 14, no. 1, pp. 519527, 2009.

[33] F. Devínsky, A. Kopecka-Leitmanová, F. Šeršeň, and P. Balgavý, "Cut-off effect in antimicrobial activity and in membrane perturbation efficiency of the homologous series of $N, N$-dimethylalkylamine oxides," Journal of Pharmacy and Pharmacology, vol. 42 , no. 11 , pp. 790-794, 1990 .
[34] P.-C. Lv, H.-Q. Li, J. Sun, Y. Zhou, and H.-L. Zhu, "Synthesis and biological evaluation of pyrazole derivatives containing thiourea skeleton as anticancer agents," Bioorganic and Medicinal Chemistry, vol. 18, no. 13, pp. 4606-4614, 2010.

[35] Y. He, Y. Wang, L. Tang et al., "Binding of puerarin to human serum albumin: a spectroscopic analysis and molecular docking," Journal of Fluorescence, vol. 18, no. 2, pp. 433-442, 2008.

[36] M. Kvasnica, J. Oklestkova, V. Bazgier, L. Rarova, K. Berka, and M. Strnad, "Biological activities of new monohydroxylated brassinosteroid analogues with a carboxylic group in the side chain," Steroids, vol. 85, pp. 58-64, 2014. 

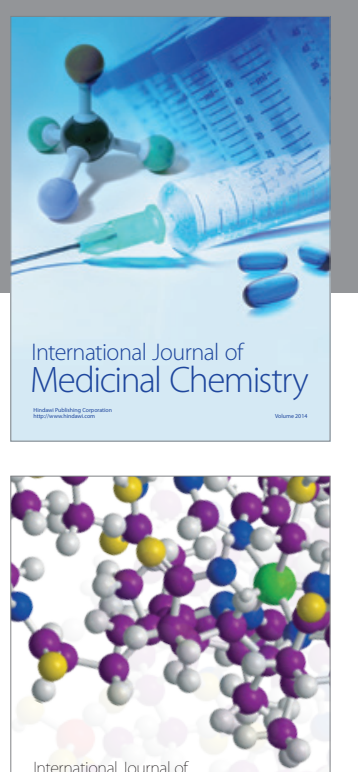

Carbohydrate Chemistry

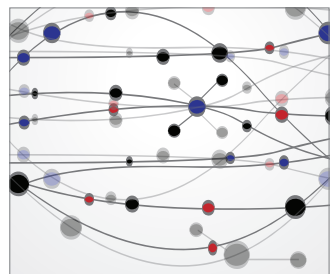

The Scientific World Journal
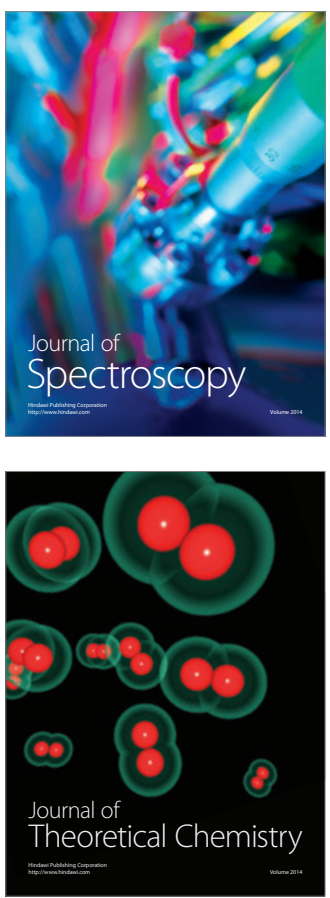
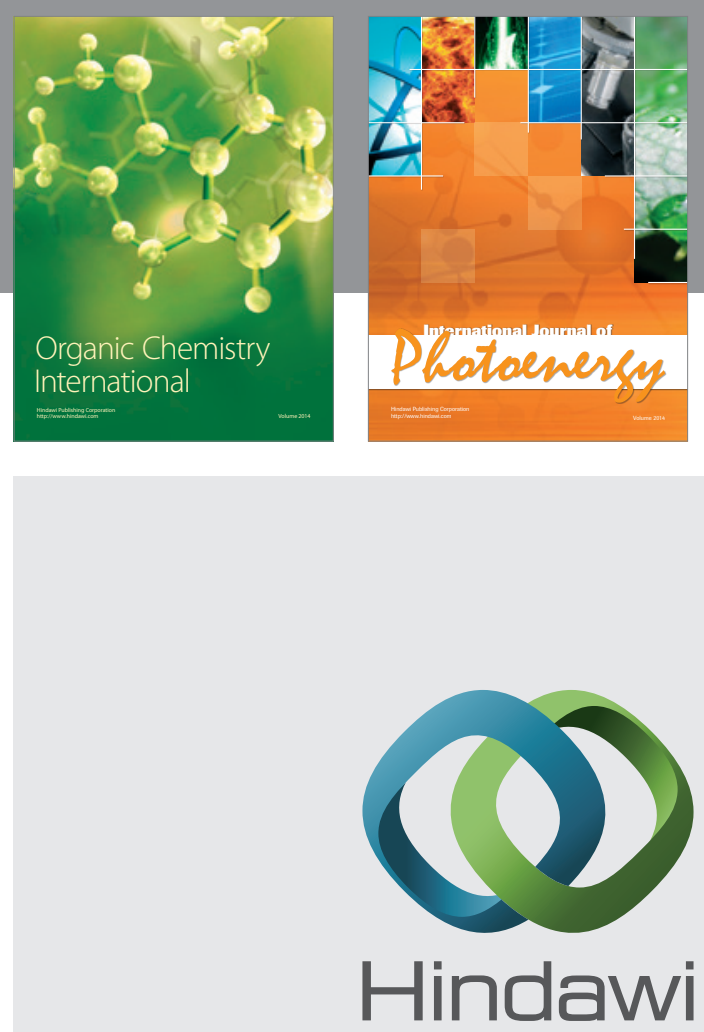

Submit your manuscripts at

http://www.hindawi.com

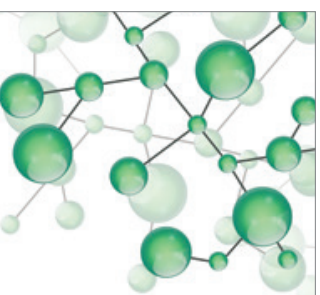

International Journal of

Inorganic Chemistry

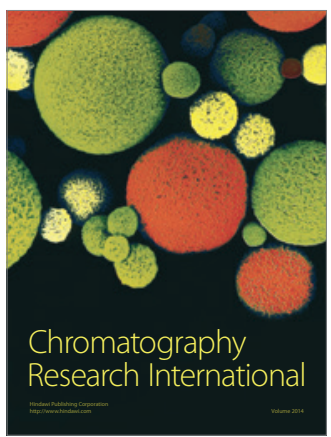

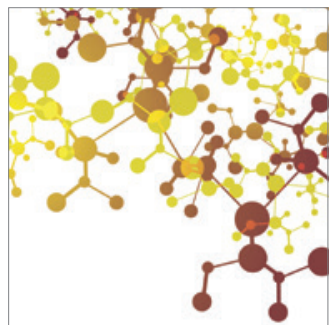

Applied Chemistry
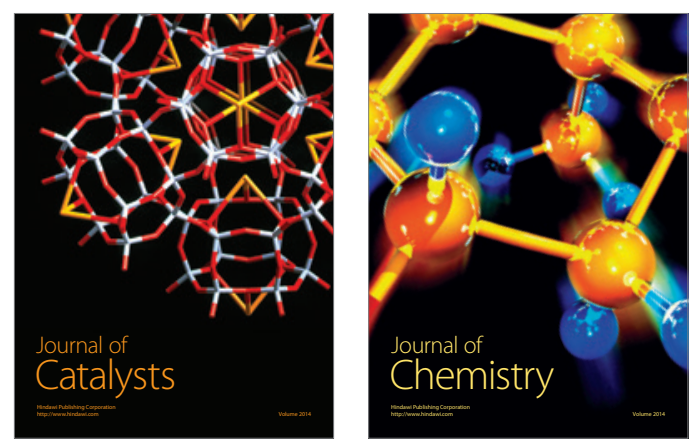
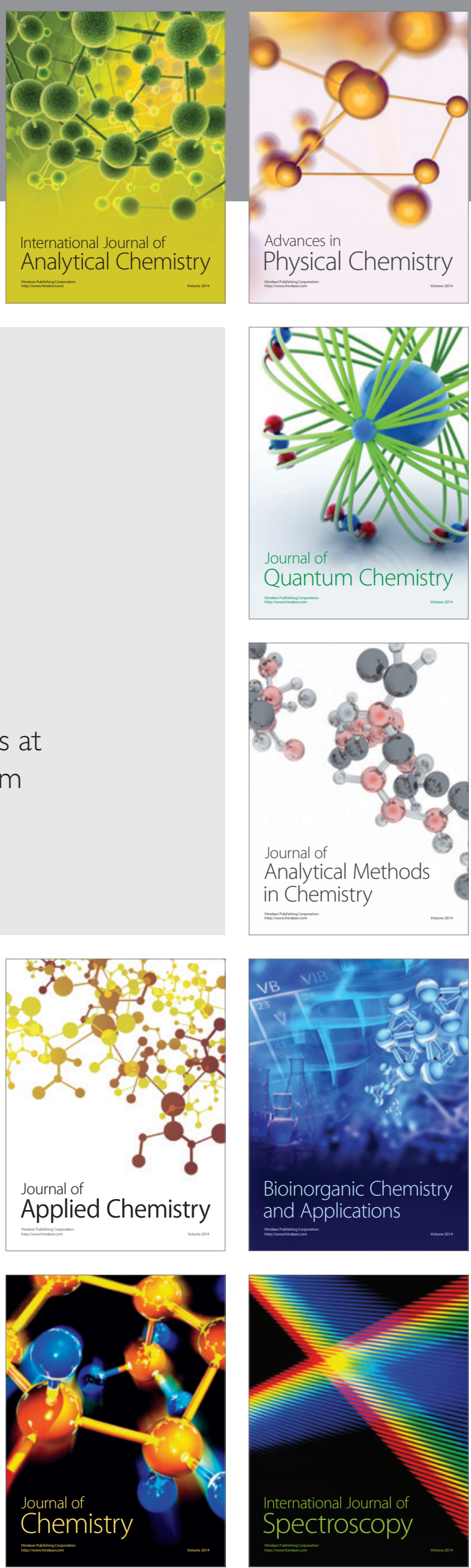